\title{
Effect of Pyrolysis Temperature and Feedstock Type on Agricultural Properties and Stability of Biochars
}

\author{
Rafaela Feola Conz ${ }^{1,2}$, Thalita F. Abbruzzini' ${ }^{1}$, Cristiano A. de Andrade ${ }^{3}$, \\ Debora M. B. P. Milori ${ }^{4}$, Carlos E. P. Cerri ${ }^{1}$ \\ ${ }^{1}$ Department of Soil Sciences, University of Sao Paulo, Piracicaba, Brazil \\ ${ }^{2}$ Department of Environmental Systems Sciences, Institute of Agricultural Sciences, Swiss Federal Institute of Technology, \\ Zurich, Switzerland \\ ${ }^{3}$ Brazilian Agricultural Research Corporation, Jaguariuna, Brazil \\ ${ }^{4}$ Brazilian Agricultural Research Corporation, Sao Carlos, Brazil \\ Email: rafaelaconz@gmail.com
}

How to cite this paper: Conz, R.F., Abbruzzini, T.F., de Andrade, C.A., Milori, D.M.B.P. and Cerri, C.E.P. (2017) Effect of Pyrolysis Temperature and Feedstock Type on Agricultural Properties and Stability of Biochars. Agricultural Sciences, 8, 914-933. https://doi.org/10.4236/as.2017.89067

Received: July 14, 2017

Accepted: August 31, 2017

Published: September 5, 2017

Copyright (c) 2017 by authors and Scientific Research Publishing Inc. This work is licensed under the Creative Commons Attribution International License (CC BY 4.0)

http://creativecommons.org/licenses/by/4.0/

\begin{abstract}
Pyrolysis temperature and feedstock type used to produce biochar influence the physicochemical properties of the obtained product, which in turn display a range of results when used as soil amendment. From soil carbon (C) sequestration strategy to nutrient source, biochar is used to enhance soil properties and to improve agricultural production. However, contrasting effects are observed from biochar application to soil results from a wide range of biochar's properties in combination with specific environmental conditions. Therefore, elucidation on the effect of pyrolysis conditions and feedstock type on biochar properties may provide basic information to the understanding of soil and biochar interactions. In this study, biochar was produced from four different agricultural organic residues: Poultry litter, sugarcane straw, rice hull and sawdust pyrolysed at final temperatures of $350^{\circ} \mathrm{C}, 450^{\circ} \mathrm{C}, 550^{\circ} \mathrm{C}$ and $650^{\circ} \mathrm{C}$. The effect of temperature and feedstock type on the variability of physicochemical properties of biochars was evaluated through measurements of $\mathrm{pH}$, electrical conductivity, cation exchange capacity, macronutrient content, proximate and elemental analyses, Fourier transform infrared spectroscopy (FTIR) and thermogravimetric analyses. Additionally, an incubation trial was carried under controlled conditions to determine the effect of biochar stability on $\mathrm{CO}_{2}$-eq emissions. Results showed that increasing pyrolysis temperature supported biochar stability regardless of feedstock, however, agricultural properties varied widely both as an effect of temperature and feedstock. Animal manure biochar showed higher potential as nutrient source rather than a
\end{abstract}


C sequestration strategy. Improving the knowledge on the influence of pyrolysis temperature and feedstock type on the final properties of biochar will enable the use of better tailored materials that correspond to the expected results while considering its interactions with environmental conditions.

\section{Keywords}

Characterization, GHG, C Sequestration, Char, Organic C

\section{Introduction}

Pyrolysis of organic residues results in a highly stable and carbonaceous material defined as biochar [1]. Pyrolysis reaction in high temperatures and low oxygen concentration produces biochar high $\mathrm{C}$ content organized in aromatic and stable structures, defined as fixed C, not available for microorganisms' degradation [2]. Particularly for wood derived biochars, this accumulation of $\mathrm{C}$ and release of less stable organic compounds, combined with lower feedstock macronutrient content, produces a highly and stable $\mathrm{C}$ containing biochar, ideal for increasing $\mathrm{C}$ content of soil [3] [4]. This supports the use of such biochar as a $C$ sequestration strategy rather than a nutrient source. Biochar can contribute to the greenhouse gas (GHG) mitigation not only due to its $\mathrm{C}$ sequestration potential [5] but also displacing the use of fossil fuel, producing alternative energy source through pyrolysis process [6]. As a global warming mitigation strategy, application of biochar in soil also showed decreasing $\mathrm{N}_{2} \mathrm{O}$ emissions. Evidence found in literature shows more than $14 \%$ decrease in $\mathrm{N}_{2} \mathrm{O}$ emissions in biochar amended soil compared to soil-only [7]. However, results are inconclusive and display variations and the underlying mechanisms explaining the effect of biochar-soil interaction include biochar properties and soil biotic and abiotic conditions [8].

Biochar produced from different feedstock type may, however, have varied concentrations of nutrients of agricultural interest. In this sense, animal manure derived biochar is shown to accumulate important elements, such as phosphorus (P), calcium (Ca) and magnesium (Mg) [9] [10]. Thus, animal manure derived biochar has higher potential to be used as a nutrient source in agricultural systems [11]. Macronutrients concentration in biochar increase during the pyrolysis process while volatile matter and water is released from biochar structure. These latter compounds are represented by organic acids, and as pyrolysis temperature increases, the release of such molecules and the accumulation of basic elements such as $\mathrm{Ca}$ and $\mathrm{Mg}$ are the drivers of high $\mathrm{pH}$ in biochars. These properties support the use of biochar as soil amendment, as liming agent and nutrient source [12].

Higher soil aggregation was also observed for fine-textured soil where wood and animal derived biochar was added [5], improving soil physical structure, aeration and moisture ratio, consequently an improved environment for root 
development. These mechanisms are often related to increased agricultural production; however, results vary due to biochar properties and its interaction with different environmental conditions [13].

It is clear that the use of the biochar can vary according to its properties, which are defined as a function of the origin/type of biomass used and the variables related to the pyrolysis process, such as time and temperature. Several outcomes are observed from the interaction of biochar and soil particles [14]. These contrasting effects are caused by the various physicochemical properties of biochar combined with environmental conditions. Thus, elucidation of the effect of pyrolysis conditions and feedstock type on biochar structure and chemical properties provide basic information to support the understanding of the resultant interactions of biochar with soil. Moreover, this knowledge also enables the selection of feedstock type and production conditions according to the environmental conditions and desired amendments for particular situations.

The purpose of this study is to present potential uses for biochar in cultivated soils considering the variation on biochar agricultural properties and $\mathrm{C}$ sequestration potential, as an effect of pyrolysis temperature and feedstock type. In this sense, we specifically aim to 1) evaluate the effect of pyrolysis temperature and feedstock type on relevant agricultural properties and $\mathrm{C}$ sequestration potential of biochar and 2) investigate the effect of contrasting biochar on GHG emission applied in tropical soil from Brazil.

\section{Materials and Methods}

\subsection{Biochar Feedstock}

Selected feedstock comprised contrasting organic residues derived from agricultural production systems: poultry litter, rice hulls, sugar cane straw and sawdust.

Poultry litter (PL) was donated and collected from the poultry facility within the Department of Genetics at the University of Sao Paulo- "Luiz de Queiroz" College of Agriculture (USP-ESALQ). These poultry are part of a sustainable farming production project developed in the department, and the posture poultry are fed daily with grass. The manure sits on the ground of the facility and it is mixed with sawdust weekly. Clean rice hull (RH) was collected in the same facility where the material is used as bedding for broiler.

Sugarcane straw (SC) was collected from a commercial sugarcane field. The straw was left over the cultivated area after harvesting operation. The Department of Forestry Sciences, in the Wood Technology and Management Laboratory, at USP-ESALQ, provided sawdust (SD). Pre-treatment included drying at $45^{\circ} \mathrm{C}$ for $24 \mathrm{~h}$ and ground to less than $1 \mathrm{~mm}$ particle size, followed by characterization analysis.

\subsection{Biochar Production}

Prior to pyrolysis, selected feedstocks were dried at $105^{\circ} \mathrm{C}$ to approximately $13 \%$ moisture $(\mathrm{w} / \mathrm{w})$ to improve the reactor efficiency. Biochars were pyrolyzed in a 
$60 \mathrm{~L}$ static reactor in $\mathrm{N}_{2}$ saturated atmosphere with a heating rate of $10^{\circ} \mathrm{C} \cdot \mathrm{min}^{-1}$. The feedstock was placed individually in the reactor chamber and heated by six electrical resistances to the temperatures of $350^{\circ} \mathrm{C}, 450^{\circ} \mathrm{C}, 550^{\circ} \mathrm{C}$ and $650^{\circ} \mathrm{C}$. Temperature was monitored by three sensors placed in the reactor, reaching its interior atmosphere close to the chamber. The reaction time varied according to each run and feedstock, and the completion was reached when the release of gases from the reactor stopped. The biochars were removed from the chamber $12 \mathrm{~h}$ after the reaction time was completed in order to avoid spontaneous combustion. The mass of all materials contained in the chamber reaction was determined in order to obtain biochar yield (Table 1).

\subsection{Feedstock and Biochar Analysis}

Feedstocks were analyzed accordingly to the same methodologies used for biochar, concerning the determinations of $\mathrm{pH}$, electrical conductivity (EC), cation exchange capacity (CEC), proximate and elemental analysis. Additionally, feedstock samples were evaluated in relation to their devolatization characteristics, through thermogravimetry analysis. Grind samples of $9 \mathrm{mg}$ were placed in a crucible with $\mathrm{N}_{2}$ gas flow with a heating rate of $10^{\circ} \mathrm{C} \cdot \mathrm{min}^{-1}$, from $25^{\circ} \mathrm{C}$ to $900^{\circ} \mathrm{C}$ (TGA-50, Shimadzu). Weight loss in respect to temperature increase was recorded.

After pyrolysis of feedstock, biochars were maintained within plastic bags tightly sealed. Prior to the analyses, air-dried biochars were ground with mortar and pestle and sieved to achieve particle size of $150-850 \mu \mathrm{m}$. Proximate and elemental analyses as well as $\mathrm{pH}$ and EC measurements were performed following the methods recommended by the International Biochar Initiative Guideline [15]. Measurements of $\mathrm{pH}$ and EC were performed in $20 \mathrm{ml}$ of deionized water mixed for 90 min with $1.0 \mathrm{~g}$ of sample [16]. pH-meter (Digimed DM-23) and conductivity-meter (Digimed DM-32) were both previously calibrated with standard solutions. CEC was determined using $0.5 \mathrm{~g}$ of biochar and $1 \mathrm{~g}$ of feedstock. Samples were mixed with $100 \mathrm{ml}$ of $\mathrm{HCl}\left(0.5 \mathrm{~mol} \cdot \mathrm{L}^{-1}\right)$ in an orbital mixer for $30 \mathrm{~min}$. Samples were filtered in vacuum, while washed with $300 \mathrm{ml}$ of deionized water divided in 10 aliquots of $30 \mathrm{ml}$ each. The residual solution was discarded. Calcium acetate $\left(0.5 \mathrm{~mol} \cdot \mathrm{L}^{-1}, \mathrm{pH}=7.0\right)$ was added to the solid sam-

Table 1. Biochar yield after pyrolysis.

\begin{tabular}{|c|c|c|c|c|}
\hline \multirow{3}{*}{ Biochar } & \multicolumn{4}{|c|}{ Yield (\%) } \\
\hline & \multicolumn{4}{|c|}{ Temperature $\left({ }^{\circ} \mathrm{C}\right)$} \\
\hline & 350 & 450 & 550 & 650 \\
\hline Sugarcane Straw (SC) & 41.5 & 37.6 & 34.6 & 32.8 \\
\hline Rice Hull (RH) & 49.6 & 49.2 & 46.5 & 46.6 \\
\hline Poultry Litter (PL) & 59.6 & 47.1 & 42.0 & 40.2 \\
\hline Sawdust (SD) & 42.6 & 42.4 & 36.4 & 33.3 \\
\hline
\end{tabular}


ples retained in the filter paper (Whatman 42) in 10 aliquots of $10 \mathrm{ml}$ each. The washing procedure using deionized water was repeated and the resultant solution was titrated using $\mathrm{NaOH}\left(0.1 \mathrm{~mol} \cdot \mathrm{L}^{-1}\right)$ to determine the amount of $\mathrm{H}^{+}$ present in the solution.

Proximate analysis methods were conducted to calculate fixed C content [17] [18]. Elemental analyses for determination of $\mathrm{C}, \mathrm{N}$ and $\mathrm{H}$ contents were assessed by dry combustion using a Perkin Elmer CNH 2400; Oxygen (O) content was obtained by subtraction [19].

The nutrient content was analyzed only for the bio-carbon samples and the procedure was based on the incineration of the samples in muffle, followed by suspension in acidic solution and determination by Inductively Coupled Plasma (ICP OES-Thermo Scientific iCAP 6300 series). Approximately $200 \mathrm{mg}$ of biochar samples were placed in crucibles and ashed in a muffle furnace for $8 \mathrm{~h}$ at $500^{\circ} \mathrm{C}$. The samples were transferred to borosilicate tubes and added $5.0 \mathrm{ml}$ of $\mathrm{HNO}_{3}$, then placed on a digestion bloc to reach temperature of $120^{\circ} \mathrm{C}$. After evaporation was complete and samples were cooled, $1.0 \mathrm{ml}$ of $\mathrm{HNO}_{3}$ plus $4 \mathrm{ml}$ of $30 \% \mathrm{H}_{2} \mathrm{O}_{2}$ were added and heated at $120^{\circ} \mathrm{C}$ to complete dryness. When cooled, concentrated $1.43 \mathrm{ml} \mathrm{HNO}_{3}$ was added and vortexed, then deionized water was added to complete $20 \mathrm{ml}$. The resultant solution was used for the determination of total P, K, Mg, S, Ca, Fe, Cu, Mn, B, Zn contents through ICP [20].

Fourier-transform infrared spectroscopy (FTIR) analysis was performed in feedstock using ground material mixed with $\mathrm{KBr}$ in a 1:500 ratio (w/w) and in biochars with 1:1000. The mixture was compacted at $5 \mathrm{Mg}$ to form pellets of 1.0 $\mathrm{cm}$ of diameter. Pellets were analyzed in a spectrometer (Perkin Elmer Spectrum 100) with $4 \mathrm{~cm}^{-1}$ resolution, measuring the absorbance from 400 to $4000 \mathrm{~cm}^{-1}$. Samples were corrected against a pure $\mathrm{KBr}$ pellet and the air as background spectrum [21].

\subsection{Incubation Experiment}

Following characterization, sugarcane straw (SC) and poultry litter (PL) biochar produced at $650^{\circ} \mathrm{C}$ and $350^{\circ} \mathrm{C}$ (SC350, SC650, PL350 and PL650) were selected to conduct an incubation trial in biochar-treated soils. Based on the results from the proximate analysis, these biochars presented higher and lower stability (SC650, PL650 and SC350, PL350 respectively) [9]. This incubation trial was performed to evaluate whether $\mathrm{CO}_{2}$-eq emission from biochar-treated soil follow trends according to biochar stability properties.

Additionally, two contrasting tropical soils were selected to investigate the effect of contrasting soil texture on biochar stability: Quartzipsament and typic Hapludox (Table 2).

Each soil respectively was collected from two different native vegetation areas located near Anhembi, Brazil ( $22^{\circ} 43^{\prime} 31.1^{\prime \prime S}$ and $\left.48^{\circ} 1^{\prime} 20.2^{\prime \prime} \mathrm{W}\right)$ and in Piracicaba, Brazil $\left(22^{\circ} 42^{\prime} 5.1^{\prime \prime} \mathrm{S}\right.$ and $\left.47^{\circ} 37^{\prime} 45.2^{\prime \prime} \mathrm{W}\right)$. The soils were sampled at the $0-20 \mathrm{~cm}$ layer, air-dried, homogenized, and sieved to $2 \mathrm{~mm}$. Contrasting biochars were 
Table 2. Soil properties for incubation experiment.

\begin{tabular}{ccc}
\hline Soil type & Quatzipsamment & Hapludox typic \\
\hline Sand $(\%)$ & 90 & 40.6 \\
Silt (\%) & 2.2 & 27.7 \\
Clay $(\%)$ & 7.8 & 31.7 \\
$\mathrm{pH}\left(\mathrm{CaCl}_{2}\right)$ & $4.0 \pm 0.1$ & $6.2 \pm 0.1$ \\
$\mathrm{C}(\%)$ & $0.9 \pm 0.1$ & $1.9 \pm 0.1$ \\
$\mathrm{~N}(\%)$ & $0.1 \pm 0.1$ & $0.2 \pm 0.1$ \\
$\mathrm{P}\left(\mathrm{mmol}_{\mathrm{c}} \cdot \mathrm{dm}^{-3}\right)$ & $28.0 \pm 1.4$ & $4.0 \pm 0.0$ \\
$\mathrm{~S}\left(\mathrm{mmol}_{\mathrm{c}} \cdot \mathrm{dm}^{-3}\right)$ & $9.5 \pm 0.7$ & $5.3 \pm 0.6$ \\
$\mathrm{~K}\left(\mathrm{mmol}_{\mathrm{c}} \cdot \mathrm{dm}^{-3}\right)$ & $4.05 \pm 0.1$ & $<0.7$ \\
$\mathrm{Ca}\left(\mathrm{mmol}_{c} \cdot \mathrm{dm}^{-3}\right)$ & $96.5 \pm 2.1$ & $5.3 \pm 0.6$ \\
$\mathrm{Mg}\left(\mathrm{mmol}_{c} \cdot \mathrm{dm}^{-3}\right)$ & $20.0 \pm 0.0$ & $<1$ \\
$\mathrm{Al}\left(\mathrm{mmol}_{c} \cdot \mathrm{dm}^{-3}\right)$ & $0.0^{(1)}$ & $5.7 \pm 0.6$ \\
$\mathrm{CEC}\left(\mathrm{mmol}_{c} \cdot \mathrm{dm}^{-3}\right)$ & $138.5 \pm 2.2$ & $69.0 \pm 4.0$ \\
\hline
\end{tabular}

${ }^{(1)}$ Values of 0.0 were near the instrument detection.

applied in each soil. The selected materials were: sugarcane and poultry litter biochars pyrolysed at $350^{\circ} \mathrm{C}$ and $650^{\circ} \mathrm{C}$. Both were added at a dose equivalent to $50 \mathrm{t} \cdot \mathrm{ha}^{-1}$ of $\mathrm{C}$ [6] in $100 \mathrm{~g}$ of soil into a $500-\mathrm{ml}$ jar with sealed lids and rubber stopper where the syringe $(50 \mathrm{ml})$ was used to removed gas samples. The sampling was performed every day for the first 10 days and in intervals of 1, 2, 3 and 4 days after the $11^{\text {th }}, 27^{\text {th }}$ and $48^{\text {th }}$ day; respectively until 56 days, during an interval of $60 \mathrm{~min}$. Moisture was maintained at $60 \%$ WHC and temperature at $25^{\circ} \mathrm{C}$, jars were placed inside an incubator without the lids. After collecting gas samples, the $\mathrm{CO}_{2}$ and $\mathrm{N}_{2} \mathrm{O}$ concentrations were measured by gas chromatograph (SRI 8610, SRI Instruments, Torrance USA) equipped in with an electron capture detector (ECD) for $\mathrm{N}_{2} \mathrm{O}$ and a flame ionization detector (FID) for $\mathrm{CO}_{2}$ detection. These results were used to estimate the fluxes calculated using the equation proposed in [3]. $\mathrm{N}_{2} \mathrm{O}$ emissions were expressed in "carbon dioxide equivalent", considering the global warming potential (GWP) of 298 for $\mathrm{N}_{2} \mathrm{O}$, compared with the GWP of carbon dioxide [22]. Total GHG $\left(\mathrm{N}_{2} \mathrm{O}+\mathrm{CO}_{2}\right.$, in $\mathrm{mg} \cdot \mathrm{kg}^{-1}$ soil) emission was represented in terms of carbon dioxide equivalent $\left(\mathrm{CO}_{2}\right.$-eq) . After incubation period, the mixture soil and biochar were evaluated for $\mathrm{pH}, \mathrm{EC}$, total $\mathrm{C}$ and $\mathrm{N}$ according to [23]. Briefly, soil samples were dried at $40^{\circ} \mathrm{C}$, ground to $1 \mathrm{~mm}$ sieve and mixed in water at 1:2.5 (w/w), shaken for $5 \mathrm{~min}$ and resting for $1 \mathrm{~h}$, followed by determination of $\mathrm{pH}$ with previously calibrated $\mathrm{pH}$-meter (Digimed DM-23) and soil samples were added in water in proportion of 1:2 $(\mathrm{w} / \mathrm{w})$, shaken for 1 hour and resting for 24 hours. The EC was determined with an EC-meter (Digimed DM-32) previously calibrated. Total C and N were determined in samples dried and sieved to 100 mesh by using an elemental analyzer (LECO-CN2000). 


\subsection{Statistical Analysis}

The effects of temperature and feedstock type were compared amongst biochars' properties using a 2-way analysis of variance (ANOVA) in a completely randomized design, with one additional treatment (original biomass). Significant differences in the factors were investigated using a Tukey's test $(p<0.05)$ to compare biochars produced with different feedstock type, and regression analysis to evaluate biochar in different pyrolysis temperature. Each biochar, originated from a single combination of feedstock and temperature, was compared with its original biomass through Dunett's test $(p<0.05)$.

The $\mathrm{CO}_{2}$-eq results obtained in the incubation experiment were submitted to ANOVA and the mean of each treatment with biochar was compared with the value of the control treatment (soil only) using Dunnett's test $(p<0.05)$. All analyses were performed using R software.

\section{Results and Discussion}

\subsection{Effects of Feedstock Type and Pyrolysis Temperature on Biochar Properties}

\subsubsection{Relevant Agricultural Properties}

Chemical analyses assessed in the present study reflected different rates of transformation for each biochar derived from contrasting feedstock. Electrical conductivity (EC) results varied with greater influence of the type of material rather than the pyrolysis temperature (Table 3). Our findings indicated that biochars can preserve the initial nutrient content, as also reported in [14]. Hence poultry litter showed the highest EC values since animal derived feedstock usually contain higher nutrient concentration [24]. In contrast with previous studies [25] [26] [27] there was no increase in EC when increasing pyrolysis temperature. Particularly for poultry litter biochars, the decrease in EC corroborated with literature when compared with its feedstock, which showed much higher values [28].

Increases in $\mathrm{pH}$ have been observed in all pyrolyzed materials and this can be explained by the effect of the temperature on the release volatile matter composed by acid functional groups and concentrates ash contents consequently elevating the $\mathrm{pH}$ [9]. Nonetheless, $\mathrm{pH}$ values followed the trend found in literature and increased with higher pyrolysis temperature (Table 3) [14] [29] [30], except for sawdust. Poultry litter biochar exhibited the highest values, corroborating with the higher amount of basic salts found in its feedstock [31]. Values of $\mathrm{pH}$ in sugarcane straw biochar were similar the data described by [29] between 8 and 10 and reflect the presence of basic elements concentrated in its composition. Particularly for rice hull, $\mathrm{pH}$ results exhibited lower values than what found in the literature [21] and reasons for that could be due to the different methodologies used to assess this property.

As a function of the loss of acidic functional groups by the action of the pyrolysis temperature, it was expected to reduce the CEC [30] [32] in comparison to 
Table 3. Basic characteristics of biochar and respective feedstock.

\begin{tabular}{|c|c|c|c|c|c|c|}
\hline & \multirow{2}{*}{ Feedstock } & \multicolumn{4}{|c|}{ Temperature of Pyrolysis $\left({ }^{\circ} \mathrm{C}\right)$} & \\
\hline & & 350 & 450 & 550 & 650 & \\
\hline \multicolumn{7}{|c|}{$\mathrm{EC}\left(\mathrm{mS} \cdot \mathrm{m}^{-1}\right)$} \\
\hline $\mathrm{SC}^{(1)}$ & 1.8 & $1.2 \mathrm{~b}^{(2)}$ & $1.4 \mathrm{~b}$ & $2.0 \mathrm{~b}^{\star(3)}$ & $1.9 \mathrm{~b}^{*}$ & $\begin{array}{c}\mathrm{y}=0.3025+0.0027 \mathrm{x} \\
\left(\mathrm{r}^{2}=0.797 ; p=0.0003\right)\end{array}$ \\
\hline $\mathrm{RH}$ & 0.8 & $0.2 \mathrm{a}$ & $0.2 \mathrm{a}$ & $0.3 \mathrm{a}$ & $0.3 \mathrm{a}$ & $\mathrm{ns}^{(4)}$ \\
\hline $\mathrm{PL}$ & 11.4 & $4.4 \mathrm{c}$ & $3.9 \mathrm{c}$ & $3.8 \mathrm{c}$ & $4.0 \mathrm{c}$ & $\begin{array}{c}\mathrm{y}=8.4609-0.0174 \mathrm{x}+1.6 \times 10^{-5} \mathrm{x}^{2} \\
\left(\mathrm{r}^{2}=0.997 ; p=0.0334\right)\end{array}$ \\
\hline \multicolumn{7}{|c|}{$\mathrm{pH}$} \\
\hline SC & 7.8 & $8.7 \mathrm{~d}^{*}$ & $8.8 c^{*}$ & $9.1 c^{*}$ & $9.2 c^{*}$ & $\begin{array}{c}\mathrm{y}=8.0200+0.0018 \mathrm{x} \\
\left(\mathrm{r}^{2}=0.907 ; p<0.0001\right)\end{array}$ \\
\hline $\mathrm{RH}$ & 6.1 & $8.4 c^{\star}$ & $8.3 \mathrm{~b}^{*}$ & $8.7 \mathrm{~b}^{*}$ & $8.7 \mathrm{~b}^{*}$ & $\begin{array}{c}\mathrm{y}=7.9275+0.0012 \mathrm{x} \\
\left(\mathrm{r}^{2}=0.617 ; p<0.0001\right)\end{array}$ \\
\hline PL & 7.3 & $8.2 b^{*}$ & $9.8 \mathrm{~d}^{*}$ & $9.8 \mathrm{~d}^{\star}$ & $9.9 \mathrm{~d}^{\star}$ & $\begin{array}{c}\mathrm{y}=-1.5314+0.0404 \mathrm{x}-3.5 \times 10^{-5} \mathrm{x}^{2} \\
\left(\mathrm{r}^{2}=0.931 ; p<0.0001\right)\end{array}$ \\
\hline $\mathrm{SD}$ & 4.0 & $7.6 \mathrm{a}^{*}$ & $7.0 \mathrm{a}^{*}$ & $7.4 \mathrm{a}^{*}$ & $7.5 \mathrm{a}^{*}$ & $\begin{array}{c}\mathrm{y}=11.2748-0.0164 \mathrm{x}-1.6 \times 10^{-5} \mathrm{x}^{2} \\
\left(\mathrm{r}^{2}=0.625 ; p<0.0001\right)\end{array}$ \\
\hline \multicolumn{7}{|c|}{$\operatorname{CEC}\left(\mathrm{mmol}_{\mathrm{c}} \cdot \mathrm{kg}^{-1}\right)$} \\
\hline SC & 190 & $280 \mathrm{bc}$ & $200 c$ & $166 \mathrm{~b}$ & $169 \mathrm{~b}$ & $\begin{array}{c}\mathrm{y}=878.896-2.436 \mathrm{x}-0.0021 \mathrm{x}^{2} \\
\left(\mathrm{r}^{2}=1.00 ; p=0.0425\right)\end{array}$ \\
\hline $\mathrm{RH}$ & 77 & 158 a & $166 \mathrm{ab}$ & $171 \mathrm{~b}$ & $165 \mathrm{ab}$ & ns \\
\hline PL & 597 & $320 c^{*}$ & $203 c^{\star}$ & $106 \mathrm{~b}^{*}$ & $105 \mathrm{ab}^{*}$ & $\begin{array}{l}\mathrm{y}=533.6833-0.6604 \mathrm{x} \\
\left(\mathrm{r}^{2}=0.929 ; p<0.0001\right)\end{array}$ \\
\hline $\mathrm{SD}$ & 303 & $207 \mathrm{ab}$ & $113 \mathrm{a}^{*}$ & $86 \mathrm{a}^{*}$ & $91 \mathrm{a}^{*}$ & $\begin{array}{c}\mathrm{y}=901.9854-2.8627 \mathrm{x}-0.0025 \mathrm{x}^{2} \\
\left(\mathrm{r}^{2}=0.994 ; p=0.0160\right)\end{array}$ \\
\hline
\end{tabular}

${ }^{(1)} \mathrm{SC}=$ sugarcane straw, $\mathrm{RH}=$ rice husk, $\mathrm{PL}=$ poultry litter, $\mathrm{SD}=$ sawdust. ${ }^{(2)}$ Means followed by the same letter are not different for biochars in the same pyrolysis temperature by Tukey's test $5 \% .{ }^{(3)}$ Means followed by an asterisk refer to differences between each biochar and its respective original biomass by Dunnett's test $5 \% .{ }^{(4)}$ Regression analysis was not significant for linear model.

the respective original biomasses and with the increase of the temperature, which was actually observed for poultry litter and sawdust (Table 3). The inverse relationship between CEC and pyrolysis temperature was also observed for sugar cane straw. The actual values of CEC are similar to values reported in literature [32], particularly for straw derived biochar, between the ranges of 100 and $230 \mathrm{mmol} \cdot \mathrm{kg}^{-1}$ and the lowest for wood derived biochars in the range of 13 and $30 \mathrm{mmol}_{\mathrm{c}} \mathrm{kg}^{-1}$. The higher mineral phase found in manure derived biochars promotes the formation of O-containing functional groups on biochar surface generating CEC, varying from 292 to $511 \mathrm{mmol}_{\mathrm{c}} \cdot \mathrm{kg}^{-1}$ [27], which can be linked with results from spectroscopic analysis showing the loss of oxygen functional groups. 
As regards the application of the biochar in the soil, it can be noticed from the results of Table 3 that lower temperatures provide a higher cation exchange capacity. Nevertheless, CEC develops with surface oxidation [12], and could potentially support CEC increase after application of biochar in the soil.

The sum of macronutrient content of animal derived biochars was higher when compared to crop residues and wood derived materials (Table 4). Poultry

Table 4. Macronutrients contents $\left(\mathrm{g} \cdot \mathrm{kg}^{-1}\right)$ in biochars and feedstock samples.

\begin{tabular}{|c|c|c|c|c|c|}
\hline \multirow{2}{*}{ Material } & \multicolumn{4}{|c|}{ Temperature of Pyrolysis $\left({ }^{\circ} \mathrm{C}\right)$} & \\
\hline & 350 & 450 & 550 & 650 & \\
\hline \multicolumn{6}{|c|}{$\mathrm{P}$} \\
\hline $\mathrm{SC}^{(1)}$ & $0.94 b^{(2)}$ & $1.67 \mathrm{c}$ & $1.99 \mathrm{c}$ & $2.73 c$ & $\begin{array}{l}\mathrm{y}=-1.0175+0.0057 \mathrm{x} \\
\left(\mathrm{r}^{2}=0.979 ; p<0.0001\right)\end{array}$ \\
\hline $\mathrm{RH}$ & $0.00^{(4)} \mathrm{a}$ & $0.00 \mathrm{a}$ & $0.00 \mathrm{a}$ & $0.00 \mathrm{a}$ & $\mathrm{ns}^{(3)}$ \\
\hline PL & $3.72 c$ & $2.13 c$ & $3.51 \mathrm{~d}$ & $4.28 \mathrm{~d}$ & $\begin{array}{c}\mathrm{y}=15.8519-0.0558 \mathrm{x}+5.9 \times 10^{-5} \mathrm{x}^{2} \\
\left(\mathrm{r}^{2}=0.742 ; p<0.0001\right)\end{array}$ \\
\hline $\mathrm{SD}$ & $1.10 \mathrm{~b}$ & $1.06 \mathrm{~b}$ & $1.03 \mathrm{~b}$ & $1.06 \mathrm{~b}$ & ns \\
\hline \multicolumn{6}{|c|}{$\mathrm{K}$} \\
\hline SC & $6.75 c$ & $9.87 \mathrm{c}$ & $10.58 \mathrm{c}$ & $13.65 c$ & $\begin{array}{l}\mathrm{y}=-0.4950+0.0214 \mathrm{x} \\
\left(\mathrm{r}^{2}=0.953 ; p<0.0001\right)\end{array}$ \\
\hline $\mathrm{RH}$ & $0.94 \mathrm{a}$ & $0.75 \mathrm{a}$ & $0.81 \mathrm{a}$ & $0.88 \mathrm{a}$ & ns \\
\hline PL & $3.13 \mathrm{~b}$ & $1.78 \mathrm{~b}$ & $2.48 \mathrm{~b}$ & $3.05 \mathrm{~b}$ & $\begin{array}{c}y=13.7939-0.0476 x+4.8 \times 10^{-5} x^{2} \\
\left(r^{2}=0.796 ; p<0.0001\right)\end{array}$ \\
\hline SD & $0.25 \mathrm{a}$ & $0.25 \mathrm{a}$ & $0.26 \mathrm{a}$ & $0.27 \mathrm{a}$ & ns \\
\hline \multicolumn{6}{|c|}{$\mathrm{Mg}$} \\
\hline SC & $2.28 \mathrm{~d}$ & $3.01 \mathrm{c}$ & $3.38 \mathrm{~d}$ & $3.66 \mathrm{~d}$ & $\begin{array}{c}y=-1.7685+0.0154 x-1.1 \times 10^{-5} x^{2} \\
\left(r^{2}=0.997 ; p=0.0005\right)\end{array}$ \\
\hline $\mathrm{RH}$ & $0.22 \mathrm{a}$ & $0.18 \mathrm{a}$ & $0.19 \mathrm{a}$ & $0.21 \mathrm{a}$ & ns \\
\hline PL & $1.16 \mathrm{c}$ & $0.74 \mathrm{~b}$ & $1.03 \mathrm{c}$ & $1.28 \mathrm{c}$ & $\begin{array}{c}\mathrm{y}=4.7262-0.0162 \mathrm{x}+1.7 \times 10^{-5} \mathrm{x}^{2} \\
\left(\mathrm{r}^{2}=0.838 ; p<0.0001\right)\end{array}$ \\
\hline $\mathrm{SD}$ & $0.65 \mathrm{~b}$ & $0.60 \mathrm{~b}$ & $0.80 \mathrm{~b}$ & $0.84 \mathrm{~b}$ & $\begin{array}{l}\mathrm{y}=0.3300+7.7 \times 10^{-4} \mathrm{x} \\
\left(\mathrm{r}^{2}=0.756 ; p=0.0043\right)\end{array}$ \\
\hline \multicolumn{6}{|c|}{$\mathrm{S}$} \\
\hline SC & $0.60 c$ & $0.92 \mathrm{~d}$ & $0.87 \mathrm{~d}$ & $1.09 \mathrm{~d}$ & $\begin{array}{c}\mathrm{y}=0.1542+0.0014 \mathrm{x} \\
\left(\mathrm{r}^{2}=0.810 ; p<0.0001\right)\end{array}$ \\
\hline $\mathrm{RH}$ & $0.10 \mathrm{a}$ & $0.06 \mathrm{a}$ & $0.09 \mathrm{a}$ & $0.09 \mathrm{a}$ & ns \\
\hline PL & $0.76 \mathrm{~d}$ & $0.39 \mathrm{c}$ & $0.60 c$ & $0.65 c$ & $\begin{array}{c}\mathrm{y}=3.1042-0.0104 \mathrm{x}+1.0 \times 10^{-5} \mathrm{x}^{2} \\
\left(\mathrm{r}^{2}=0.608 ; p<0.0001\right)\end{array}$ \\
\hline SD & $0.29 \mathrm{~b}$ & $0.26 \mathrm{~b}$ & $0.26 \mathrm{~b}$ & $0.26 \mathrm{~b}$ & ns \\
\hline
\end{tabular}

${ }^{(1)} \mathrm{SC}=$ sugarcane straw, $\mathrm{RH}=$ rice husk, $\mathrm{PL}=$ poultry litter, $\mathrm{SD}=$ sawdust. ${ }^{(2)}$ Means followed by the same letter are not different for biochars in the same pyrolysis temperature by Tukey's test $5 \% .{ }^{(3)}$ Regression analysis was not significant for linear and quadratic models. ${ }^{(4)}$ Values of 0.00 were near the instrument detection. 
litter biochar showed the greatest values for macronutrients especially due to high content of $\mathrm{Ca}$, which explains the higher $\mathrm{pH}$ determined for this material [25]. Contents of $\mathrm{P}$ and $\mathrm{K}$ found in the present study were lower than other results found in the literature, which could be due to differences in methodology to determine concentration of elements, and heterogeneity of poultry litter feedstock [10] [27]. Even though the concentrations dropped with temperature increase, poultry litter biochar conserved higher amounts of the analyzed elements, when compared to the other materials studied, indicating its potential use as fertilizer [28].

Sugarcane straw biochars showed intermediate concentration of macronutrient, and consistent increase in these elements when pyrolysis temperature rose (Table 4). This material is characterized by higher content of $\mathrm{K}$ when compared to the other macronutrients due to the higher concentration of such element in its feedstock [29].

By contrast, rice hull and sawdust biochars showed very low concentration of macronutrients, and little to no variability in the concentration of the elements, when pyrolysis temperature rose (Table 4). Lower contents of nutrients in plant straw and wood derived materials when compared to animal manure biochars, regardless of pyrolysis temperature are showed in literature [30].

Nevertheless, the total amount of macronutrient determined has no relation to the supply of available nutrients [12] when biochar is added in the soil. Similarly, the initial concentration of nutrients in biochars feedstock did not secured the concentration in its biochars after the pyrolysis process. Thus, neither feedstock material nor pyrolysis temperature are good indicators of the final nutrient concentration in the biochars [10].

Micronutrients contents showed little to no variability in relation to temperature increase, for the majority of biochar samples (Table 5), only differences for the metallic micronutrients $\mathrm{Fe}, \mathrm{Mn}$ and $\mathrm{Zn}$.

Sugarcane straw biochar exhibited the highest concentration of micronutrients, especially due to the high amount of iron ( $\mathrm{Fe}$ ), that could be explained by contamination with soil, since the straw was removed from the field and was not washed before being placed inside the reactor chamber. Other element concentrated in sugarcane biochar was manganese $(\mathrm{Mn})$, with linear increase as a function of temperature, reaching a maximum of $0.11 \mathrm{ppm}$ when pyrolyzed at $650^{\circ} \mathrm{C}$.

Poultry litter exhibited the highest concentration of zinc ( $\mathrm{Zn}$ ) reaching 0.09 $\mathrm{ppm}$, which is reflecting the common addition of $\mathrm{Zn}$ as a supplement in poultry diet [33]. These results represent the potential use of biochars as soil amendment.

\subsubsection{Stability Indicators}

Proximate analysis (Table 6) is an approach to evaluate recalcitrance of biochars, and its components vary mostly between different feedstocks than due to temperature increase [9]. For instance, large proportions of ash content are ex- 
Table 5. Micronutrients contents $\left(\mathrm{mg} \cdot \mathrm{kg}^{-1}\right)$ in biochars and feedstock samples.

\begin{tabular}{|c|c|c|c|c|c|}
\hline \multirow{2}{*}{ Material } & \multicolumn{4}{|c|}{ Temperature of Pyrolysis $\left({ }^{\circ} \mathrm{C}\right)$} & \\
\hline & 350 & 450 & 550 & 650 & \\
\hline \multicolumn{6}{|c|}{$\mathrm{Fe}$} \\
\hline $\mathrm{SC}^{(1)}$ & $10.15 b^{(2)}$ & $5.88 \mathrm{~b}$ & $6.24 \mathrm{~b}$ & $3.68 \mathrm{~b}$ & $\begin{array}{c}\mathrm{y}=26.0954-0.0615 \mathrm{x}+4.3 \times 10^{-5} \mathrm{x}^{2} \\
\left(\mathrm{r}^{2}=0.869 ; p<0.0001\right)\end{array}$ \\
\hline $\mathrm{RH}$ & $0.08 \mathrm{a}$ & $0.06 \mathrm{a}$ & $0.02 \mathrm{a}$ & $0.06 \mathrm{a}$ & $\mathrm{ns}^{(3)}$ \\
\hline PL & $0.44 \mathrm{a}$ & $0.34 \mathrm{a}$ & $0.45 \mathrm{a}$ & $0.56 \mathrm{a}$ & ns \\
\hline SD & $0.49 \mathrm{a}$ & $0.49 \mathrm{a}$ & $0.44 \mathrm{a}$ & $0.51 \mathrm{a}$ & ns \\
\hline \multicolumn{6}{|c|}{$\mathrm{Mn}$} \\
\hline SC & $0.07 \mathrm{~b}$ & $0.08 \mathrm{~b}$ & $0.08 \mathrm{c}$ & $0.11 \mathrm{c}$ & $\begin{aligned} \mathrm{y} & =0.0242+0.001 \mathrm{x} \\
\left(\mathrm{r}^{2}\right. & =0.778 ; p<0.0001)\end{aligned}$ \\
\hline RH & $0.04 \mathrm{a}$ & $0.04 \mathrm{a}$ & $0.02 \mathrm{a}$ & $0.04 \mathrm{a}$ & ns \\
\hline PL & $0.05 \mathrm{a}$ & $0.04 \mathrm{a}$ & $0.05 \mathrm{~b}$ & $0.07 \mathrm{~b}$ & $\begin{array}{c}\mathrm{y}=0.1939-0.0007 \mathrm{x}+10^{-6} \mathrm{x}^{2} \\
\left(\mathrm{r}^{2}=0.940 ; p=0.0011\right)\end{array}$ \\
\hline $\mathrm{SD}$ & $0.05 \mathrm{a}$ & $0.04 \mathrm{a}$ & $0.05 \mathrm{~b}$ & $0.06 \mathrm{~b}$ & $\begin{array}{l}\mathrm{y}=0.0267-4.0 \times 10^{-5} \mathrm{x} \\
\left(\mathrm{r}^{2}=0.720 ; p<0.0395\right)\end{array}$ \\
\hline \multicolumn{6}{|c|}{$\mathrm{Zn}$} \\
\hline $\mathrm{SC}$ & $0.03 \mathrm{a}$ & $0.03 \mathrm{bc}$ & $0.03 \mathrm{a}$ & $0.04 \mathrm{~b}$ & ns \\
\hline RH & $0.01 \mathrm{a}$ & $0.01 \mathrm{a}$ & $0.01 \mathrm{a}$ & $0.02 \mathrm{a}$ & ns \\
\hline PL & $0.09 \mathrm{~b}$ & $0.05 \mathrm{c}$ & $0.08 \mathrm{~b}$ & $0.08 \mathrm{c}$ & $\begin{array}{c}\mathrm{y}=0.3421-0.0011 \mathrm{x}+10^{-6} \mathrm{x}^{2} \\
\left(\mathrm{r}^{2}=0.493 ; p=0.0001\right)\end{array}$ \\
\hline SD & $0.03 \mathrm{a}$ & $0.02 \mathrm{ab}$ & $0.01 \mathrm{a}$ & $0.02 \mathrm{a}$ & ns \\
\hline
\end{tabular}

${ }^{(1)} \mathrm{SC}=$ sugarcane straw, $\mathrm{RH}=$ rice husk, $\mathrm{PL}=$ poultry litter, $\mathrm{SD}=$ sawdust. ${ }^{(2)}$ Means followed by the same letter are not different for biochars in the same pyrolysis temperature by Tukey's test $5 \% .{ }^{(3)}$ Regression analysis was not significant for linear and quadratic models.

Table 6. Proximate analysis if biochar and feedstock samples.

\begin{tabular}{|c|c|c|c|c|c|c|}
\hline \multirow{2}{*}{ Material } & \multicolumn{5}{|c|}{ Temperature of Pyrolysis $\left({ }^{\circ} \mathrm{C}\right)$} & \\
\hline & Feedstock & 350 & 450 & 550 & 650 & \\
\hline \multicolumn{7}{|c|}{ Volatile Matter (\%) } \\
\hline $\mathrm{SC}^{(1)}$ & 90.6 & $50.1 \mathrm{~b}^{(2) \star}$ & $45.2 \mathrm{~b}^{\star(3)}$ & $44.0 c^{*}$ & $43.8 \mathrm{~b}^{\star}$ & $\begin{array}{c}\mathrm{y}=55.8667-0.0201 \mathrm{x} \\
\left(\mathrm{r}^{2}=0.772 ; p=0.0010\right)\end{array}$ \\
\hline RH & 77.0 & $25.8 \mathrm{a}^{\star}$ & $26.5 \mathrm{a}^{*}$ & $24.2 \mathrm{a}^{*}$ & $28.0 \mathrm{a}^{\star}$ & $\mathrm{ns}^{(4)}$ \\
\hline PL & 69.7 & $60.8 c^{*}$ & $46.9 \mathrm{bc}^{\star}$ & $45.7 c^{*}$ & $42.1 \mathrm{~b}^{*}$ & $\begin{array}{c}\mathrm{y}=139.0231-0.3163 \mathrm{x}+2.6 \times 10^{-4} \mathrm{x}^{2} \\
\left(\mathrm{r}^{2}=0.944 ; p=0.0002\right)\end{array}$ \\
\hline $\mathrm{SD}$ & 93.6 & $54.0 \mathrm{~b}^{\star}$ & $50.0 c^{*}$ & $35.3 \mathrm{~b}^{*}$ & $29.1 \mathrm{a}^{*}$ & $\begin{array}{l}\mathrm{y}=86.8058-0.0894 \mathrm{x} \\
\left(\mathrm{r}^{2}=0.953 ; p<0.0001\right)\end{array}$ \\
\hline \multicolumn{7}{|c|}{ Ash (\%) } \\
\hline SC & 8.5 & $24.2 \mathrm{~b}^{*}$ & $16.0 \mathrm{~b}^{*}$ & $17.0 \mathrm{~b}^{*}$ & $13.3 \mathrm{~b}^{*}$ & $\begin{array}{c}\mathrm{y}=60.2596-0.1447 \mathrm{x}+1.1 \times 10^{-4} \mathrm{x}^{2} \\
\left(\mathrm{r}^{2}=0.848 ; p=0.0055\right)\end{array}$ \\
\hline $\mathrm{RH}$ & 19.5 & $40.4 c^{*}$ & $40.5 c^{*}$ & $42.0 c^{*}$ & $42.0 c^{*}$ & ns \\
\hline
\end{tabular}




\section{Continued}

\begin{tabular}{|c|c|c|c|c|c|c|}
\hline PL & 29.7 & $38.2 c^{*}$ & $51.0 \mathrm{~d}^{*}$ & $50.3 \mathrm{~d}^{*}$ & $48.8 \mathrm{~d}^{*}$ & $\begin{array}{c}\mathrm{y}=-53.5375+0.3893 \mathrm{x}+3.7 \times 10^{-4} \mathrm{x}^{2} \\
\left(\mathrm{r}^{2}=0.927 ; p<0.0001\right)\end{array}$ \\
\hline SD & 1.2 & $1.2 \mathrm{a}$ & $0.9 \mathrm{a}$ & $1.0 \mathrm{a}$ & $1.2 \mathrm{a}$ & $\mathrm{ns}$ \\
\hline \multicolumn{7}{|c|}{ Fixed Carbon (\%) } \\
\hline SC & $0.0^{(5)}$ & $21.9 \mathrm{~b}^{*}$ & $35.2 c^{*}$ & $35.2 b^{*}$ & $38.7 c^{*}$ & $\begin{array}{c}\mathrm{y}=-51.1921+0.2976 \mathrm{x}+2.5 \times 10^{-4} \mathrm{x}^{2} \\
\left(\mathrm{r}^{2}=0.915 ; p=0.0005\right)\end{array}$ \\
\hline RH & 0.0 & $31.0 c^{*}$ & $29.5 b^{*}$ & $30.8 \mathrm{~b}^{*}$ & $27.2 b^{*}$ & $\mathrm{~ns}$ \\
\hline PL & 0.0 & $0.0 \mathrm{a}$ & $1.0 \mathrm{a}$ & $2.8 \mathrm{a}$ & $7.5 \mathrm{a}^{*}$ & $\begin{array}{l}\mathrm{y}=-12.6417+0.0300 \mathrm{x} \\
\left(\mathrm{r}^{2}=0.967 ; p<0.0001\right)\end{array}$ \\
\hline SD & 0.0 & $41.5 \mathrm{~d}^{*}$ & $45.6 \mathrm{~d}^{*}$ & $60.3 c^{*}$ & $66.5 \mathrm{~d}^{*}$ & $\begin{array}{c}\mathrm{y}=8.5892-0.0897 \mathrm{x} \\
\left(\mathrm{r}^{2}=0.954 ; p<0.0001\right)\end{array}$ \\
\hline
\end{tabular}

${ }^{(1)} \mathrm{SC}=$ sugarcane straw, $\mathrm{RH}=$ rice husk, $\mathrm{PL}=$ poultry litter, $\mathrm{SD}=$ sawdust. ${ }^{(2)}$ Means followed by the same letter are not different for biochars in the same pyrolysis temperature by Tukey's test $5 \% .{ }^{(3)}$ Means followed by an asterisk refer to differences between each biochar and its respective original biomass by Dunnett test $5 \%$. ${ }^{(4)}$ Regression analysis was not significant for linear and quadratic models. ${ }^{(5)}$ Values of 0.00 were near the instrument detection.

hibited by poultry litter biochar, which corroborates with literature [9]. Animal derived biochar composition reached approximately $50 \%$ of ash content and between $45 \%$ and $60 \%$ of volatile matter similar to the results reported by [27] [28].

Larger proportions of ash are found in crop residues than in wood derived biochar due to higher nutrient concentration on the former feedstock [9]. Values from $24 \%$ to $34 \%$ were found for rice straw decreasing with higher temperature [21] and around 37\% were also reported for rice husk biochar produced at $500^{\circ} \mathrm{C}[32]$. For sugarcane straw biochar, ash values found in the literature are scarce but fall in the range of $11 \%$ to $13 \%$ increasing with temperature [29].

The unexpected decrease in ash content for this material might be explained by the volatilization of elements such as $\mathrm{P}, \mathrm{K}$ and $\mathrm{S}$, which can occur at lower temperatures as $500^{\circ} \mathrm{C}$ [9]. The values reported for sawdust varied from more than $10 \%$ to $1 \%$ according to the type of wood and the particle size of the materials [30] [34] [35]. Ash content increases in higher temperatures, due to the release of labile components, enhancing the mineral phase proportion. Fixed $\mathrm{C}$ is regarded as the recalcitrant $\mathrm{C}$ remaining within biochar composition after thermal degradation caused by pyrolysis [1]. Fixed $C$ content is mostly influenced by the type of feedstock than by pyrolysis temperature in the production process, even though all materials showed increase in content of fixed $\mathrm{C}$ while temperature increased [30]. In this sense, the content of fixed $\mathrm{C}$ in biochar derived from wood materials is relatively higher when compared to the different biochars, particularly when compared to poultry manure (Table 6). The higher ash content in the feedstock, the less effect of increasing fixed $\mathrm{C}$ in higher temperature [9]. Therefore, wood derived biochars produced at higher temperature have increased potential to sequester $\mathrm{C}$ in soil by adding organic $\mathrm{C}$ in stable forms. 
Increasing pyrolysis temperature decreased the concentration of $\mathrm{O}$ and $\mathrm{H}$ and increased $\mathrm{C}$ of all materials. This reflects the decrease in surface reactivity and thus higher stability of biochars. Although $C$ content (Table 7) was initially similar among feedstocks, the difference in concentration for each material became larger after pyrolysis [9].

This is due to the fact that each material accumulates $\mathrm{C}$ at different rates with increasing temperature, and most of plant based biochar show high quantities of $\mathrm{C}$ in relation to other nutrients, which is the opposite trend found in biochars derived from manures [12]. For instance, poultry litter (30\% to $40 \%)$ showed slightly decreasing content with increasing temperature. High ash materials, such as animal manure biochar, have high inorganic $\mathrm{C}$ content bound to carbo-

Table 7. Elemental composition of biochar and feedstock samples.

\begin{tabular}{|c|c|c|c|c|c|c|}
\hline \multirow{2}{*}{\multicolumn{2}{|c|}{$\begin{array}{c}\text { Material } \\
\text { Feedstock }\end{array}$}} & \multicolumn{4}{|c|}{ Temperature of Pyrolysis } & \\
\hline & & $350^{\circ} \mathrm{C}$ & $450^{\circ} \mathrm{C}$ & $550^{\circ} \mathrm{C}$ & $650^{\circ} \mathrm{C}$ & \\
\hline \multicolumn{7}{|c|}{ Carbon (\%) } \\
\hline $\mathrm{SC}^{(1)}$ & 42.4 & $60.1 \mathrm{~b}^{(2) *}$ & $65.6 c^{\star(3)}$ & $67.6 c^{*}$ & $69.4 c^{*}$ & $\begin{array}{l}\mathrm{y}=50.8267+0.0297 \mathrm{x} \\
\left(\mathrm{r}^{2}=0.917 ; p=0.0001\right)\end{array}$ \\
\hline $\mathrm{RH}$ & 36.1 & $32.8 \mathrm{a}$ & $48.6 \mathrm{~b}^{*}$ & $49.1 \mathrm{~b}^{*}$ & $49.5 \mathrm{~b}^{*}$ & $\begin{array}{c}\mathrm{y}=-71.8981+0.4236 \mathrm{x}+3.9 \times 10^{-4} \mathrm{x}^{2} \\
\left(\mathrm{r}^{2}=0.941 ; p<0.0001\right)\end{array}$ \\
\hline PL & 30.4 & $38.1 \mathrm{a}^{\star}$ & $29.8 \mathrm{a}$ & $35.3 \mathrm{a}$ & $32.6 \mathrm{a}$ & $\mathrm{ns}^{(4)}$ \\
\hline SD & 45.6 & $71.6 c^{*}$ & $72.4 \mathrm{~d}^{*}$ & $79.8 \mathrm{~d}^{*}$ & $84.6 \mathrm{~d}^{*}$ & $\begin{array}{l}\mathrm{y}=53.9725+0.0463 \mathrm{x} \\
\left(\mathrm{r}^{2}=0.929 ; p<0.0001\right)\end{array}$ \\
\hline \multicolumn{7}{|c|}{ Oxygen (\%) } \\
\hline SC & 50.5 & $35.8 \mathrm{~b}^{*}$ & $30.0 \mathrm{~b}^{*}$ & $29.2 \mathrm{~b}^{*}$ & $26.7 \mathrm{~b}^{*}$ & $\begin{array}{c}\mathrm{y}=44.4900-0.0281 \mathrm{x} \\
\left(\mathrm{r}^{2}=0.892 ; p=0.0009\right)\end{array}$ \\
\hline $\mathrm{RH}$ & 58.6 & $66.1 \mathrm{~d}^{*}$ & $49.4 c^{\star}$ & $49.4 c^{*}$ & $49.0 c^{*}$ & $\begin{array}{c}\mathrm{y}=79.0567-0.0512 \mathrm{x} \\
\left(\mathrm{r}^{2}=0.617 ; p<0.0001\right)\end{array}$ \\
\hline $\mathrm{PL}$ & 62.0 & $55.9 \mathrm{c}$ & $68.5 \mathrm{~d}^{*}$ & $61.5 \mathrm{~d}$ & $65.1 \mathrm{~d}$ & $\begin{array}{c}\mathrm{y}=-1.0937+0.2462 \mathrm{x}+2.3 \times 10^{-4} \mathrm{x}^{2} \\
\left(\mathrm{r}^{2}=0.471 ; p=0.0129\right)\end{array}$ \\
\hline SD & 48.4 & $24.3 \mathrm{a}^{*}$ & $22.9 \mathrm{a}^{*}$ & $16.6 \mathrm{a}^{*}$ & $12.4 \mathrm{a}^{*}$ & $\begin{array}{l}\mathrm{y}=40.2542-0.0424 \mathrm{x} \\
\left(\mathrm{r}^{2}=0.951 ; p<0.0001\right)\end{array}$ \\
\hline \multicolumn{7}{|c|}{ Hydrogen (\%) } \\
\hline SC & 6.1 & $2.4 \mathrm{~b}^{*}$ & $2.8 \mathrm{a}^{*}$ & $2.2 \mathrm{~b}^{*}$ & $2.5 \mathrm{~b}^{*}$ & ns \\
\hline $\mathrm{RH}$ & 5.1 & $1.1 \mathrm{a}^{\star}$ & $2.0 c^{\star}$ & $1.5 \mathrm{a}^{\star}$ & $1.5 \mathrm{a}^{\star}$ & $\begin{array}{c}\mathrm{y}=-4.3064+0.0237 \mathrm{x}+2.3 \times 10^{-5} \mathrm{x}^{2} \\
\left(\mathrm{r}^{2}=0.595 ; p=0.0043\right)\end{array}$ \\
\hline PL & 4.5 & $3.4 c^{*}$ & $1.7 \mathrm{a}^{*}$ & $1.4 \mathrm{a}^{*}$ & $0.9 \mathrm{a}^{*}$ & $\begin{array}{c}\mathrm{y}=12.9610-0.0383 \mathrm{x}+3.1 \times 10^{-5} \mathrm{x}^{2} \\
\left(\mathrm{r}^{2}=0.953 ; p=0.0003\right)\end{array}$ \\
\hline $\mathrm{SD}$ & 6.0 & $3.9 c^{*}$ & $4.1 \mathrm{~b}^{*}$ & $3.2 c^{*}$ & $2.8 \mathrm{~b}^{*}$ & $\begin{aligned} \mathrm{y} & =5.6183-0.0042 \mathrm{x} \\
\left(\mathrm{r}^{2}\right. & =0.815 ; p<0.0001)\end{aligned}$ \\
\hline
\end{tabular}

${ }^{(1)} \mathrm{SC}=$ sugarcane straw, $\mathrm{RH}=$ rice husk, $\mathrm{PL}=$ poultry litter, $\mathrm{SD}=$ sawdust. ${ }^{(2)}$ Means followed by the same letter are not different for biochars in the same pyrolysis temperature by Tukey's test $5 \% .{ }^{(3)}$ Means followed by an asterisk refer to differences between each biochar and its respective original biomass by Dunnett test $5 \%{ }^{(4)}$ Regression analysis was not significant for linear and quadratic models. 
nates, which can decrease the C by $24 \%$ [9] [36]. Biochars derived from sugarcane straw exhibited total $\mathrm{C}$ values ranging from $67 \%$ to $73 \%$ [29] while for rice hull biochar results varied from $36 \%$ to $39 \%$ [32]. For wood derived biochars, as sawdust feedstock, total C content showed largest variation with increasing temperature, ranging from $51 \%$ to $77 \%$. Nitrogen content varied within feedstock, exhibiting highest values for sugarcane straw (1.43\%) and poultry litter biochars $(1.46 \%)$, and the lowest for sawdust $(0.3 \%)$ and rice hull biochars $(0.02 \%)$. However, contrary to literature [9], $\mathrm{N}$ regression analysis was not significant for linear and quadratic models, showing no variability with temperature increase. Hydrogen and oxygen contents decreased in all biochars. This is an indication of carbonization and aromatization of carbon structures during pyrolysis reaction, and it is reflected in the lower reactivity of biochars as temperature increases [37].

FTIR spectroscopy results of all biochars exhibited flattening of bands located between 3200 and $3400 \mathrm{~cm}^{-1}$ with increasing temperature (Figure 1), indicating less intensity of the $\mathrm{O}-\mathrm{H}$ stretching due to dehydration [38].

All biochar samples showed decrease in the intensity of the band at $1700 \mathrm{~cm}^{-1}$ after pyrolysis process, which indicates the release of carbonyl and carboxyl organic groups, and is also associated to CEC reduction. Moreover, FTIR spectroscopy showed that with higher temperature the broadening and flattening for all biochar spectra indicates loss of labile aliphatic compounds [25] and maintenance of more recalcitrant compounds, such as aromatic chains. Specifically to the stretching at $2900 \mathrm{~cm}^{-1}$, all samples showed flattening representing the loss of aliphatic $\mathrm{C}-\mathrm{H}$ bond [21]. The pyrolysis of cellulose, hemicellulose and lignin was indicated by the absence of functional groups, which was more noticeable for the sugarcane straw and sawdust biochars, around $1030 \mathrm{~cm}^{-1}$ [10] [39].

The three main components of biomass; hemicellulose, cellulose and lignin have different chemical structures and thus, correspondingly thermal stability [40]. Thermogravimetric analysis (Figure 2) indicated the thermal decomposi-

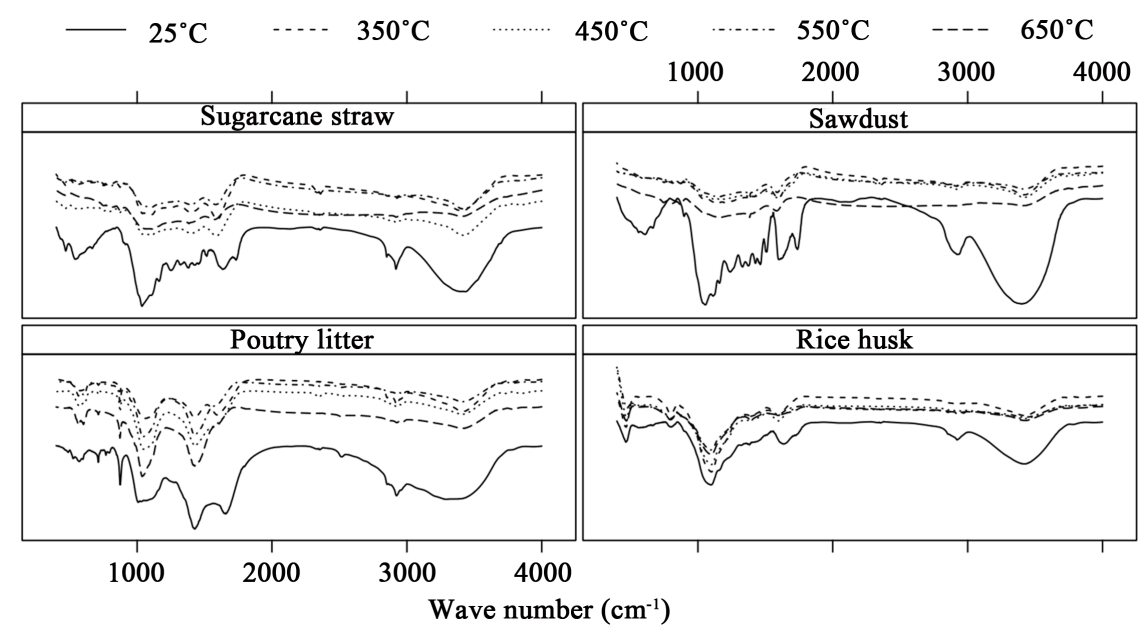

Figure 1. FTIR spectra displayed for all treatments of all biochar samples and feedstock. 


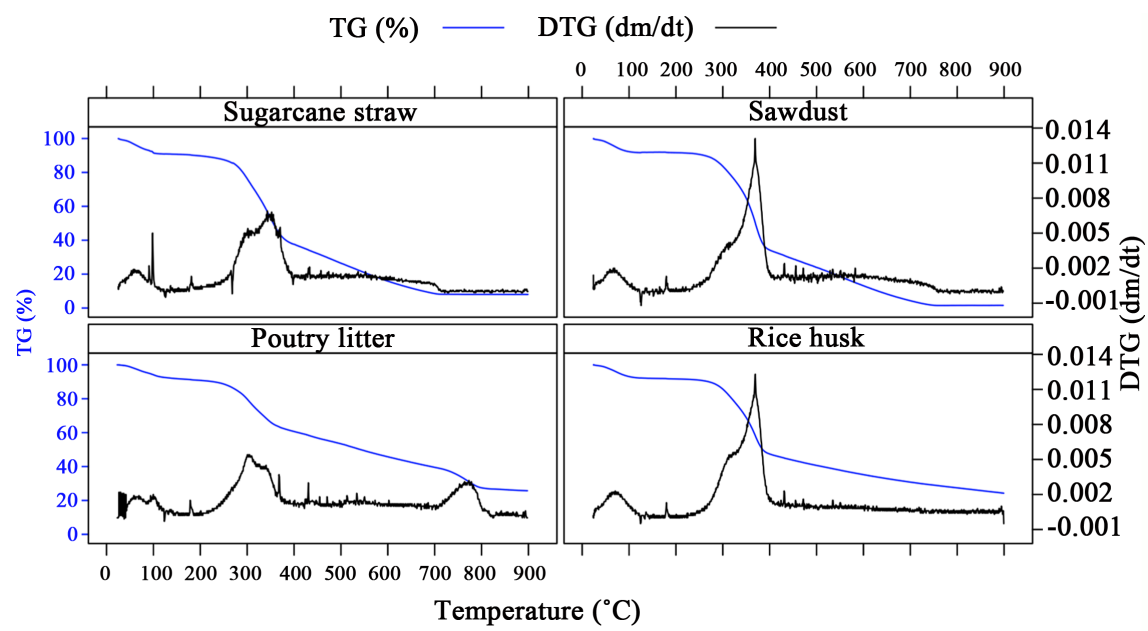

Figure 2. Results from thermogravimetric analysis in all treatments. TG (\%) is the cumulative mass loss in temperature increase, and DTG $(\mathrm{dm} / \mathrm{dt})$ is the derivative of the TG curve.

tion behavior of lignocellulosic component for each biomass [39]. In all materials, the mass loss within the first stage of temperature increased, up to $105^{\circ} \mathrm{C}$, indicating water release. The peaks observed between temperatures of $200^{\circ} \mathrm{C}$ to $300^{\circ} \mathrm{C}$ and $300^{\circ} \mathrm{C}$ to $400^{\circ} \mathrm{C}$ relate to the release of hemicellulose and cellulose, respectively [34]. Lignin has a much higher molecular weight and during pyrolysis it decomposes over a wider range of temperature, contributing for the formation of condensed aromatic carbon in biochar's structure [40]. The interval between $300^{\circ} \mathrm{C}$ and $400^{\circ} \mathrm{C}$ is the highest for all samples from $20 \%$ to $50 \%$ mass loss, the highest value exhibited by sawdust and the lowest by poultry litter. Sugarcane straw and rice hull lost about $38 \%$ of its mass in the same range of temperature.

This corroborates with high cellulose contents in wood materials and low in animal manure. The cumulative mass loss was the lowest in poultry manure and rice hull within the temperature range analyzed (from $25^{\circ} \mathrm{C}$ to $900^{\circ} \mathrm{C}$ ), which was also found by [11] [34].

\subsubsection{Biochar Amended Soils and $\mathrm{CO}_{2}$-Eq Emission}

In both soil types, the cumulative $\mathrm{CO}_{2}$-eq emissions in sugarcane straw and poultry litter biochar amended soils presented similar results when each treatment was compared to control (Table 8) excluding poultry litter biochar pyrolysed at $350^{\circ} \mathrm{C}$. As shown previously, biochar from poultry litter has higher ash content and volatile matter in comparison with sugarcane straw biochars in both pyrolysis temperatures (Table 6).

The higher proportion of volatile matter determined in the poultry litter biochar (Table 6) indicates higher amount of easily degradable source of $\mathrm{C}$, enabling its use by the microorganisms, which in turn cause soil respiration to spike when comparing to control treatment. In sandy soils, lower initial C content was incremented, amongst other elements that were also added to the soil with poul- 
Table 8. Cumulative $\mathrm{CO}_{2}$-eq emissions, total $\mathrm{C}$ and $\mathrm{N}$ and $\mathrm{EC}$ from clayey soil incubated with sugarcane and poultry litter biochars pyrolysed at $350^{\circ} \mathrm{C}$ and $650^{\circ} \mathrm{C}$.

\begin{tabular}{|c|c|c|c|c|c|}
\hline Feedstock & $\begin{array}{c}\text { Pyrolysis } \\
\text { Temp. }\end{array}$ & $\begin{array}{c}\mathrm{CO}_{2} \text { eq } \\
\text { cumulative } \\
\left(\mathrm{mg} \cdot \mathrm{kg} \cdot \mathrm{soil}^{-1}\right)\end{array}$ & $\begin{array}{l}\text { Total } \\
\mathrm{N}(\%)\end{array}$ & $\begin{array}{l}\text { Total } \\
\text { C (\%) }\end{array}$ & $\begin{array}{c}\text { EC } \\
\left(\mathrm{mS} \cdot \mathrm{m}^{-1}\right)\end{array}$ \\
\hline \multicolumn{6}{|c|}{ Typic Hapludox } \\
\hline \multirow{2}{*}{$\mathrm{SC}^{(1)}$} & $350^{\circ} \mathrm{C}$ & $153.94 \pm 16.1$ & $0.43 \pm 0.01^{\star(1)}$ & $5.38 \pm 0.04^{*}$ & $134.70 \pm 4.12^{\star}$ \\
\hline & $650^{\circ} \mathrm{C}$ & $153.52 \pm 24.55$ & $0.40 \pm 0.03^{*}$ & $5.40 \pm 0.18^{*}$ & $114.30 \pm 4.43$ \\
\hline \multirow{2}{*}{ PL } & $350^{\circ} \mathrm{C}$ & $251.01 \pm 43.89^{*}$ & $0.51 \pm 0.02^{*}$ & $4.76 \pm 0.09^{*}$ & $242.61 \pm 19.37^{*}$ \\
\hline & $650{ }^{\circ} \mathrm{C}$ & $163.12 \pm 29.62$ & $0.39 \pm 0.01^{*}$ & $4.90 \pm 0.09^{*}$ & $236.07 \pm 18.40^{*}$ \\
\hline \multicolumn{2}{|c|}{ Control } & $185.55 \pm 35.7$ & $0.29 \pm 0.01$ & $2.92 \pm 0.06$ & $106.08 \pm 19.42$ \\
\hline \multicolumn{6}{|c|}{ Quartzipsament } \\
\hline \multirow{2}{*}{ SC } & $350^{\circ} \mathrm{C}$ & $163.45 \pm 34.94$ & $0.19 \pm 0.01^{\star}$ & $3.09 \pm 0.21^{\star}$ & $82.42 \pm 2.31^{\star}$ \\
\hline & $650^{\circ} \mathrm{C}$ & $129.82 \pm 13.22$ & $0.14 \pm 0.03^{*}$ & $2.74 \pm 0.06^{*}$ & $94.91 \pm 1.40^{*}$ \\
\hline \multirow{2}{*}{ PL } & $350^{\circ} \mathrm{C}$ & $348.95 \pm 47.49^{*}$ & $0.24 \pm 0.01^{*}$ & $2.41 \pm 0.11^{*}$ & $231.17 \pm 11.44^{*}$ \\
\hline & $650^{\circ} \mathrm{C}$ & $103.05 \pm 38.79$ & $0.13 \pm 0.01^{*}$ & $2.58 \pm 0.14^{*}$ & $253.48 \pm 6.87^{\star}$ \\
\hline \multicolumn{2}{|c|}{ Control } & $136.01 \pm 22.81$ & $0.09 \pm 0.01$ & $0.74 \pm 0.08$ & $28.20 \pm 5.16$ \\
\hline
\end{tabular}

${ }^{(1)} \mathrm{SC}=$ sugarcane straw, $\mathrm{PL}=$ poultry litter. ${ }^{(2)}$ Means followed by an asterisk refer to differences between each biochar and its respective original biomass by Dunnett test $5 \%$.

try litter biochar application, enabling microbial degradation which reflected in higher $\mathrm{CO}_{2}$-eq emission. The lower reactivity of sandy soils, demonstrated by lower CEC (Table 2), is unable to buffer the addition of biochar in the soil [41]. The higher $\mathrm{CO}_{2}$-eq emissions in poultry litter biochar amended soils is also reflected in the lower total $\mathrm{C}$ determined in the samples at the end of the incubation period. These aforementioned treatments showed the lowest levels of total $\mathrm{C}$, indicating that the $\mathrm{C}$ added with biochar was metabolized and emitted, while the higher values, presented by sugarcane straw biochar treated soil corroborate the persistence of highly stable $\mathrm{C}$ structures. As the less recalcitrant material, poultry litter biochar at $350^{\circ} \mathrm{C}$, was a readily available $\mathrm{C}$ and $\mathrm{N}$ source for soil microorganisms to perform mineralization.

\section{Conclusions}

This study demonstrated how pyrolysis reaction affects biochar properties depending on the temperature range and the feedstock type. During pyrolysis, contrasting feedstock showed similar trends, such as the increase in $\mathrm{pH}$ values, and the concentration of macronutrients such as $\mathrm{P}, \mathrm{K}, \mathrm{Ca}$ and $\mathrm{Mg}$. The extent of these trends however, occurred differently. Stability indicators showed same results, where release of $\mathrm{O}$ and $\mathrm{H}$, while accumulation of $\mathrm{C}$ were influenced by the initial contents of such elements in each of the feedstocks.

It is essential to note that agricultural properties, that support the use of biochar as nutrient source, were improved in manure derived biochars, while C sta- 
bility was lower. Contrastingly, wood derived biochars developed higher stability and have potential to be applied as $\mathrm{C}$ sequestration strategy; however, did not exhibit properties of agricultural interest. Biochars produced from crop residues showed intermediary properties and have the potential to fulfill both functions in soil. Specifically, the use of sugarcane straw biochar as $\mathrm{C}$ sequestration strategy is encouraged in this study, considering that $\mathrm{CO}_{2}$-eq emissions of biochar treated soils were similar to soil-only treatments. Further analysis should be carried to investigate the potential of sugarcane biochar as a nutrient source in cropping systems.

Overall these results demonstrate the potential of biochar as soil amendment, the selection of biochar for agricultural purposes or as a C sequestration strategy, however, must consider the biochar's chemical properties along with the environmental conditions and expected results after application.

\section{Acknowledgements}

We thank the São Paulo Research Foundation (FAPESP) and National Council for Scientific and Technological Development (CNPq) for financial support, the Department of Soil Science at the College of Agriculture "Luiz de Queiroz" and the Center for Nuclear Energy in Agriculture from the University of São Paulo for providing technical support.

\section{References}

[1] Lehmann, J. and Joseph, S. (2009) Biochar for Environmental Management: An Introduction. In: Lehmann, J. and Joseph, S., Eds., Biochar for Environmental Management. Science and Technology, Routledge, Abingdon, 416.

[2] Luo, L., Xu, C., Chen, Z. and Zhang, S. (2015) Properties of Biomass-Derived Biochars: Combined Effects of Operating Conditions and Biomass Types. Bioresource Technology, 192, 83-89. https://doi.org/10.1016/j.biortech.2015.05.054

[3] Mukome, F.N.D., Zhang, X., Silva, L.C.R., Six, J. and Parikh, S.J. (2013) Use of Chemical and Physical Characteristics to Investigate Trends in Biochar Feedstocks. Journal of Agricultural and Food Chemistry, 61, 2196-2204. https://doi.org/10.1021/jf3049142

[4] Wang, J., Xiong, Z. and Kuzyakov, Y. (2016) Biochar Stability in Soil: Meta-Analysis of Decomposition and Priming Effects. GCB Bioenergy, 8, 512-523. https://doi.org/10.1111/gcbb.12266

[5] Wang, D., Fonte, S.J., Parikh, S.J., Six, J. and Scow, K.M. (2017) Biochar Additions Can Enhance Soil Structure and the Physical Stabilization of C in Aggregates. Geoderma, 303, 110-117. https://doi.org/10.1016/j.geoderma.2017.05.027

[6] Woolf, D., Amonette, J.E., Street-Perrott, F.A., Lehmann, J. and Joseph, S.D. (2010) Biochar as Carbon Negative in Carbon Credit under Changing Climate. Nature Communications, 1-56.

[7] Singh, B.P., Hatton, B.J., Singh, B., Cowie, A.L. and Kathuria, A. (2010) Influence of Biochars on Nitrous Oxide Emission and Nitrogen Leaching from Two Contrasting Soils. Journal of Environmental Quality, 39, 1224-1235. https://doi.org/10.2134/jeq2009.0138 
[8] Van Zwieten, L., et al. (2014) An Incubation Study Investigating the Mechanisms that Impact $\mathrm{N}_{2} \mathrm{O}$ Flux from Soil Following Biochar Application. Agriculture, Ecosystems \& Environment, 191, 53-62. https://doi.org/10.1016/j.agee.2014.02.030

[9] Enders, A., Hanley, K., Whitman, T., Joseph, S.D. and Lehmann, J. (2012) Characterization of Biochars to Evaluate Recalcitrance and Agronomic Performance. Bioresource Technology, 114, 644-653. https://doi.org/10.1016/j.biortech.2012.03.022

[10] Cantrell, K.B., Hunt, P.G., Uchimiya, M., Novak, J.M. and Ro, K.S. (2012) Impact of Pyrolysis Temperature and Manure Source on Physicochemical Characteristics of Biochar. Bioresource Technology, 107, 419-428. https://doi.org/10.1016/j.biortech.2011.11.084

[11] Azargohar, R., Nanda, S., Kozinski, J.A., Dalai, A.K. and Sutarto, R. (2014) Effects of Temperature on the Physicochemical Characteristics of Fast Pyrolysis Bio-Chars Derived from Canadian Waste Biomass. Fuel, 125, 90-100.

https://doi.org/10.1016/j.fuel.2014.01.083

[12] Ippolito, J.A., Spokas, K.A., Novak, J.M., Lentz, R.D. and Cantrell, K.B. (2015) Biochar Elemental Composition and Factors Influencing Nutrient Retention. In: Lehmann, J. and Joseph, S.D., Eds., Biochar for Environmental Management. Science, Technology and Implementation, Earthscan, 137-162.

[13] Lorenz, K. and Lal, R. (2014) Biochar Application to Soil for Climate Change Mitigation by Soil Organic Carbon Sequestration. Journal of Plant Nutrition and Soil Science, 177, 651-670. https://doi.org/10.1002/jpln.201400058

[14] Joseph, S.D., et al. (2010) An Investigation into the Reactions of Biochar in Soil. Australian Journal of Soil Research, 48, 501-515. https://doi.org/10.1071/SR10009

[15] IBI (2015) Standardized Product Definition and Product Testing Guidelines for Biochar that Is Used in Soil, International Biochar Initiative. http://www.biochar-international.org/characterizationstandard

[16] Rajkovich, S., et al. (2012) Corn Growth and Nitrogen Nutrition after Additions of Biochars with Varying Properties to a Temperate Soil. Biology and Fertility of Soils, 48, 271-284. https://doi.org/10.1007/s00374-011-0624-7

[17] ASTM International ASTM D1762-84. (2007) Standard Test Method for Chemical Analysis of Wood Charcoal. ASTM International 1-2, West Conshohocken.

[18] ASTM International. ASTMD 3172-13. (2013) Standard Practice for Proximate Analysis of Coal and Coke. ASTM International 1-2, West Conshohocken.

[19] Kim, K.H., Kim, J.Y., Cho, T.S. and Choi, J.W. (2012) Influence of Pyrolysis Temperature on Physicochemical Properties of Biochar Obtained from the Fast Pyrolysis of Pitch Pine (Pinus rigida). Bioresource Technology, 118, 158-162. https://doi.org/10.1016/j.biortech.2012.04.094

[20] Enders, A. and Lehmann, J. (2012) Comparison of Wet-Digestion and Dry-Ashing Methods for Total Elemental Analysis of Biochar. Communications in Soil Science and Plant Analysis, 43, 1042-1052. https://doi.org/10.1080/00103624.2012.656167

[21] Wu, W., et al. (2012) Chemical Characterization of Rice Straw-Derived Biochar for Soil Amendment. Biomass and Bioenergy, 47, 268-276.

[22] Myhre, G., et al. (2013) Anthropogenic and Natural Radiative Forcing. In: Stocker, T.F., et al., Eds., Climate Change 2013: The Physical Science Basis. Contribution of Working Group I to the Fifth Assessment Report of the Intergovernmental Panel on Climate Change, Cambridge University Press, Cambridge.

[23] Embrapa (1997) Manual de Metodos de Analise de Solo. 2nd Edition. 
[24] Singh, B., Singh, B.P. and Cowie, A.L. (2010) Characterisation and Evaluation of Biochars for Their Application as a Soil Amendment. Australian Journal of Soil Research, 48, 516-525. https://doi.org/10.1071/SR10058

[25] Kloss, S., et al. (2012) Characterization of Slow Pyrolysis Biochars: Effects of Feedstocks and Pyrolysis Temperature on Biochar Properties. Journal of Environmental Quality, 41, 990-1000. https://doi.org/10.2134/jeq2011.0070

[26] Oh, T.-K., Choi, B., Shinogi, Y. and Chikushi, J. (2012) Characterization of Biochar Derived from Three Types of Biomass. Journal of the Faculty of Agriculture, 57, 6166.

[27] Song, W. and Guo, M. (2012) Quality Variations of Poultry Litter Biochar Generated at Different Pyrolysis Temperatures. Journal of Analytical and Applied Pyrolysis, 94, 138-145. https://doi.org/10.1016/j.jaap.2011.11.018

[28] Meng, J., et al. (2013) Physicochemical Properties of Biochar Produced from Aerobically Composted Swine Manure and Its Potential Use as an Environmental Amendment. Bioresource Technology, 142, 641-646. https://doi.org/10.1016/j.biortech.2013.05.086

[29] Melo, L.C.A., Coscione, A.R., Abreu, C.A., Puga, A.P. and Camargo, O.A. (2013) Influence of Pyrolysis Temperature on Cadmium and Zinc Sorption Capacity of Sugar Cane Straw-Derived Biochar. BioResource, 8, 4992-5004. https://doi.org/10.15376/biores.8.4.4992-5004

[30] Zhao, L., Cao, X., Mašek, O. and Zimmerman, A.R. (2013) Heterogeneity of Biochar Properties as a Function of Feedstock Sources and Production Temperatures. Journal of Hazardous Materials, 256-257, 1-9. https://doi.org/10.1016/j.jhazmat.2013.04.015

[31] Lehmann, J., et al. (2011) Biochar Effects on Soil Biota-A Review. Soil Biology and Biochemistry, 43, 1812-1836. https://doi.org/10.1016/j.soilbio.2011.04.022

[32] Wang, Y., Hu, Y., Zhao, X., Wang, S. and Xing, G. (2013) Comparisons of Biochar Properties from Wood Material and Crop Residues at Different Temperatures and Residence Times. Energy and Fuels, 27, 5890-5899. https://doi.org/10.1021/ef400972z

[33] Park, S., Birkhold, S., Kubena, L., Nisbet, D. and Ricke, S. (2004) Review on the Role of Dietary Zinc in Poultry Nutrition, Immunity, and Reproduction. Biological Trace Element Research, 101, 147-163. https://doi.org/10.1385/BTER:101:2:147

[34] Ghani, W.A.K., et al. (2013) Biochar Production from Waste Rubber-Wood-Sawdust and Its Potential Use in C Sequestration: Chemical and Physical Characterization. Industrial Crops and Products Journal, 44, 18-24.

[35] Mukherjee, A., Zimmerman, A.R. and Harris, W. (2011) Surface Chemistry Variations among a Series of Laboratory-Produced Biochars. Geoderma, 163, 247-255. https://doi.org/10.1016/j.geoderma.2011.04.021

[36] Cimo, G., et al. (2014) Effect of Heating Time and Temperature on the Chemical Characteristics of Biochar from Poultry Manure. Journal of Agricultural and Food Chemistry, 62, 1912-1918. https://doi.org/10.1021/jf405549z

[37] Chan, K.Y. and Xu, Z. (2009) Biochar: Nutrient Properties and Their Enhancement. In: Lehmann, J. and Joseph, S.D., Eds., Biochar for Environmental Management. Science and Technology 2009, Earthscan, 416.

[38] Mimmo, T., Panzacchi, P., Baratieri, M., Davies, C.A. and Tonon, G. (2014) Effect of Pyrolysis Temperature on Miscanthus (Miscanthus $\times$ Giganteus) Biochar Physical, Chemical and Functional Properties. Biomass and Bioenergy, 62, 149-157. 
https://doi.org/10.1016/j.biombioe.2014.01.004

[39] Nanda, S., Azargohar, R., Kozinski, J.A. and Dalai, A.K. (2014) Characteristic Studies on the Pyrolysis Products from Hydrolyzed Canadian Lignocellulosic Feedstocks. Bioenergy Research, 7, 174-191. https://doi.org/10.1007/s12155-013-9359-7

[40] Lee, Y., et al. (2013) Comparison of Biochar Properties from Biomass Residues Produced by Slow Pyrolysis at $500^{\circ}$ C. Bioresource Technology, 148, 196-201. https://doi.org/10.1016/j.biortech.2013.08.135

[41] Mukherjee, A., Lal, R. and Zimmerman, A.R. (2014) Effects of Biochar and Other Amendments on the Physical Properties and Greenhouse Gas Emissions of an Artificially Degraded Soil. Science of the Total Environment, 487, 26-36.

https://doi.org/10.1016/j.scitotenv.2014.03.141

Submit or recommend next manuscript to SCIRP and we will provide best service for you:

Accepting pre-submission inquiries through Email, Facebook, LinkedIn, Twitter, etc. A wide selection of journals (inclusive of 9 subjects, more than 200 journals)

Providing 24-hour high-quality service

User-friendly online submission system

Fair and swift peer-review system

Efficient typesetting and proofreading procedure

Display of the result of downloads and visits, as well as the number of cited articles

Maximum dissemination of your research work

Submit your manuscript at: http://papersubmission.scirp.org/

Or contact as@scirp.org 